\title{
The Long History of Lost Wax Casting
}

\section{OVER FIVE THOUSAND YEARS OF ART AND CRAFTSMANSHIP}

\section{L.B. Hunt}

Johnson Matthey \& Co. Limited, London, U.K.

The origins of lost wax or investment casting, often known as cire perdue, and still the most accurate and reliable means of reproducing complex shapes in gold or other metals with all the fine detail of an original pattern, go back to the very first civilisations in the Near East and to a combination of primitive art, religion and metallurgy. The historical development of the process and its several variations are reviewed here as well as its transmission to other parts of the world.

The discovery that metals could be melted and cast to shape in moulds was one of the major strides towards civilisation made by early man. Some time before 4000 B.C., almost certainly independently in several different regions, and after long experiment with coloured minerals like malachite and azurite that had attracted his attention, man began the smelting of copper. There is no certainty about the dates of this first step in metallurgy nor about the exact locations, but in Anatolia, in the highlands of Iran, in Syria and Palestine, and even in Thailand, there is evidence of smelting around this time.

The next stage was of course the casting of copper in simple open moulds made of stone or less often in clay to produce simple tools, to be followed by the use of two-part moulds in which both faces of the object could be fashioned. These first smelting and casting operations were undoubtedly carried out in a crude type of kiln or furnace with some forced draught developed for the making of pottery, and the early metal worker would have needed the cooperation of the potter not only for this purpose but also for the production of his crucibles. Potters in these times were well accustomed to the making of small human and animal figures, representations either naturalistic or symbolic used as votive objects to please the numerous gods associated with early religions in the

Among the very earliest lost wax castings known are small figures of animals mounted on pins and dowelled into the centre of cylinder seals, devices used before the invention of writing to form a characteristic impression on moist clay as an indication of ownership or agreement to a transaction. This seal, carved with figures of cattle, carries a recumbent ram cast in copper and comes from the Uruk period in Mesopotamia, around 3500 B.C.

Photograph by courtesy of the Ashmolean Museum, University of Oxford
Near East and elsewhere. Such statuettes had for many centuries also been carved in various types of stone, while small human figures were often made in beeswax either as religious symbols or, when thrown on to a fire, as a means of removing or avoiding a curse from an enemy.

At an unknown date somewhere in the middle of the fourth millenium B.C. - again possibly independently in more than one region - either a potter

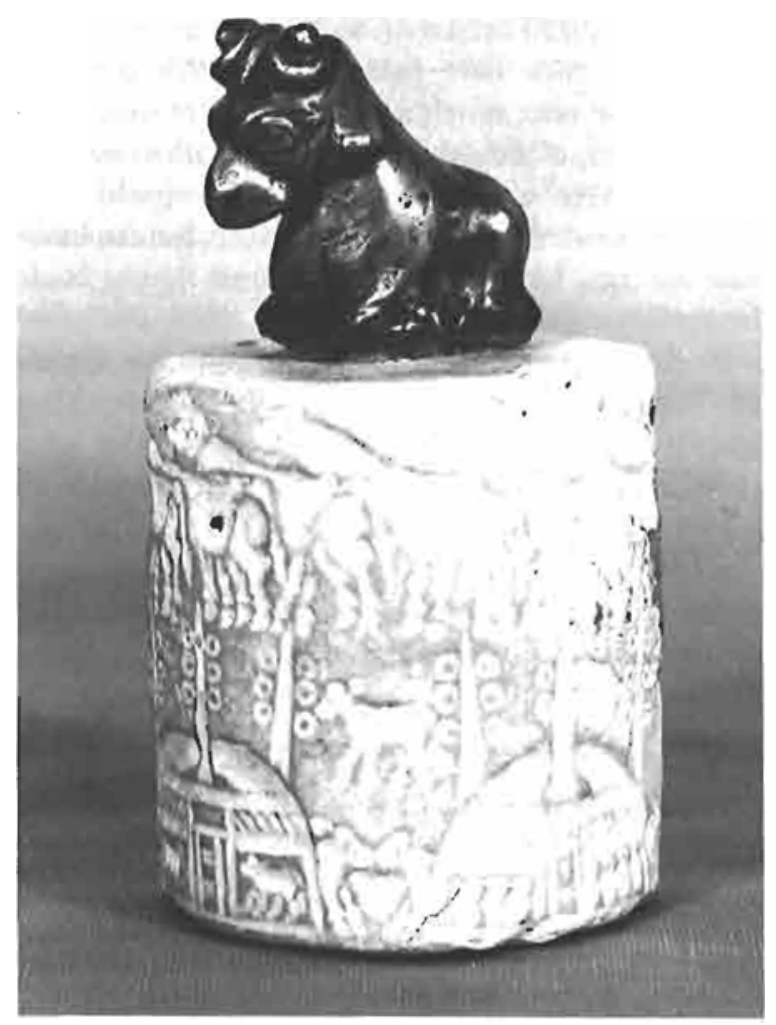




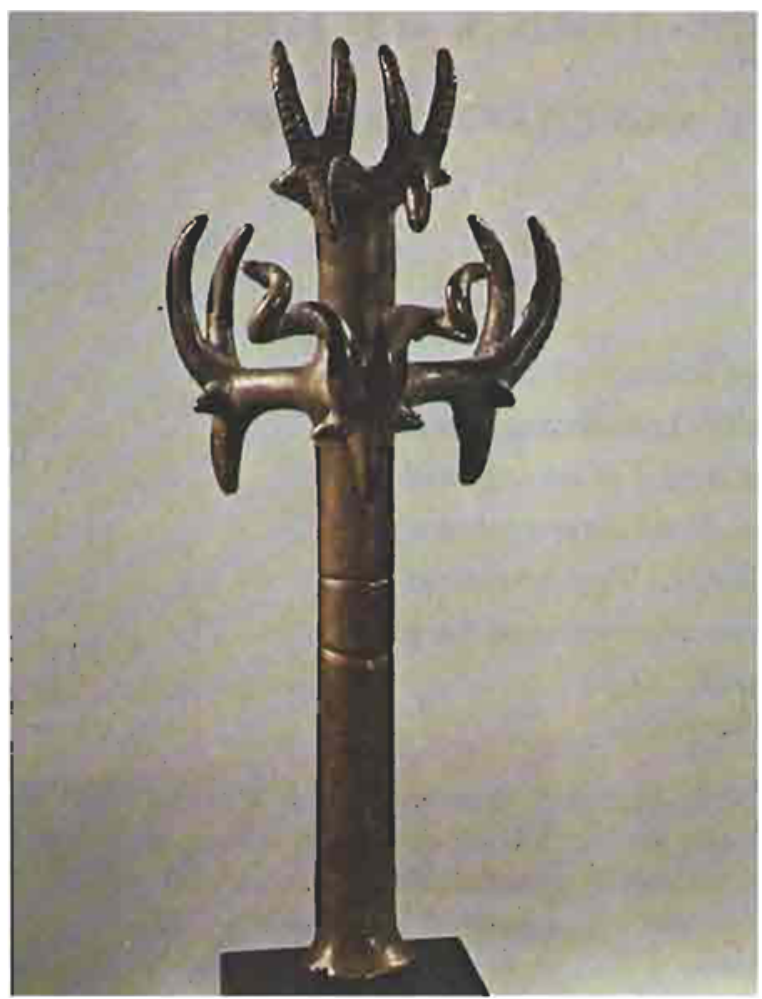

or a metal worker, or more probably the two working together, conceived the brilliant idea of taking a model carved in beeswax, coating this with clay, heating the composite structure both to harden the clay and to melt out the wax, and then using the mould so formed to produce a more complex casting with every detail carved or built up in the wax. This innovation must have been greeted with great enthusiasm; at once much more elaborate objects could be produced, of almost any shape and with several advantages over earlier techniques. Compared with stone, by modelling rather than carving, human limbs and the legs, horns and tails of animal figures could be represented much more readily, while compared with clay a great improvement in strength was achieved. Wax was available from wild bees, and was in fact already a commodity in use for several other purposes, while the keeping of bees was introduced at an early time in most parts of western Asia.

This was the beginning of lost wax casting, often referred to by archaeologists in its French form, cire perdue. The earliest castings were made in relatively

Although by no means the earliest lost wax casting to have been found, this copper model of a chariot drawn by four wild asses and driven by a bearded Sunterian king is the most elaborate from an early period. Dated to about 2850 B.C., it was excavated near the high altar in a temple at Tell Agrab, norlh east of modern Baghdad, and is now in the Iraq Musenm there. Although heavily corroded, it shows great skill in both modelling and casting. It is 7 centimetres in height

Photograph by Hirmer Verlag, Munich
Some of the most astonishingly complex losl wax castings, made in arsenical copper, were found in 1961 hidden in an aluost inaccessible cave at Nahal Mislnnar overlooking the western shore of the Dead Sea in Israel. Among a hoard of more than four hundred castings were several elaborate sceptres or standards such as this, terminating in ibex heads and showing an exceptionally high standard of workmanship for such a period - around 3200 B.C. when Syria and Palestine appear to have been an independent centre of early metallurgy

Photograph by courtesy of the Israel Museum, Jerusalem

pure copper but very soon an arsenical copper was introduced, to be followed by tin bronze, and a little later by gold.

Some of the earliest examples of lost wax castings in copper include the figures of recumbent animals mounted on cylinder seals carved from limestone or magnesite - a device in use in Mesopotamia and elsewhere before the invention of writing that could be rolled across a piece of moist clay as a mark of ownership or of assent to an agreement - and dated to about 3500 B.C. From the same period, but from Elam in south western Iran, a number of large dress pins, now in the Louvre, have representations of crouching ibex and other animals (1), while from only a few centuries later, similar castings have been found at Troy and at Poliochni, a settlement on the Greek island of Lemos closely associated with Troy (2).

One or two small bronze figures and the spouts and fittings for some bronze vessels that could have been cast only by the lost wax process, as well as gold dress pins with decorative heads, come from the early cities of Troy, where the accumulation of wealth attracted skilled goldsmiths from western Asia.

Even more complicated specimens were discovered among a spectacular hoard in a cave at Nahal Mishmar close to the western shore of the Dead Sea,

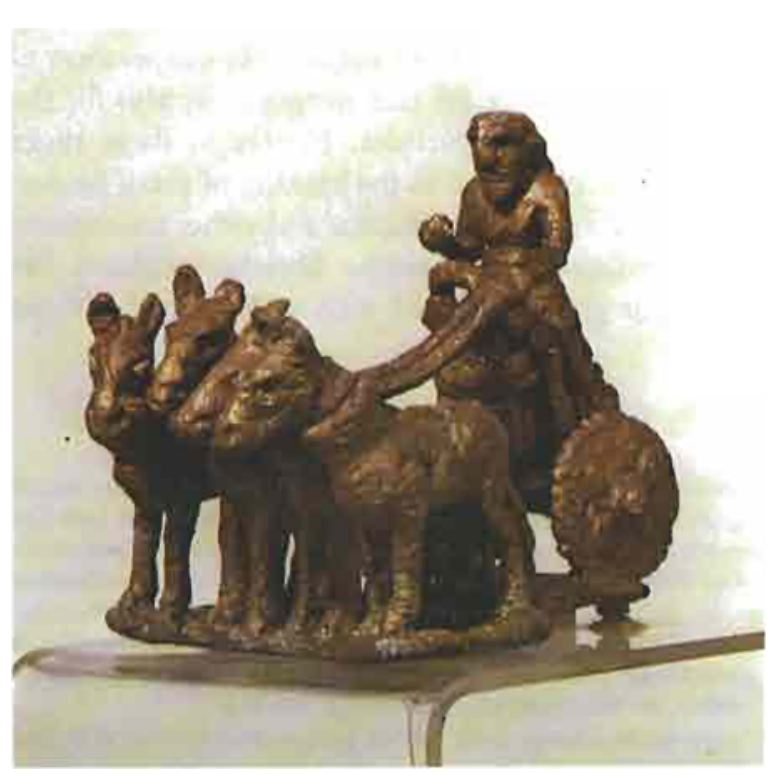


From the royal centery at Ur in Mesopotamia, excavated by Sir leeonard Woolley and ascribed to around 2600 B.C., there emerged anong many other objects of gold this terret or rein ring from the sledge-chariot of Queen Pu-Abi. Soldered to the top of the silver base is the queen's mascot, an onager or wild ass, lost wax cast in electrum, the natural alloy of gold and silver. Woolley described it as "an astonishingly fine piece of realistic sculpture and one of the most charning objects that the cemetery has produced'

Photograph by courtesy of the Trustees of the British Museum

all these being attributed to the early Bronze Age, around 3200 B.C., but all revealing a lengthy experience in the technique and displaying a perfection of detail (3).

\section{Early Progress in Mesopotamia}

It was, however, in the land of Sumer, the southern part of Mesopotamia between the Tigris and the Euphrates, that metallurgy in general and lost wax casting in particular developed most effectively. This was a region devoid of minerals and metals, and supplies of copper had to be imported either from Oman to the south or from Anatolia to the north. Indications of this trade remain in the earlier name of the Euphrates - Urudu, the copper river - while supplies of gold were secured either from Elam, from Anatolia, or from Bactria in modern Afghanistan.

The earliest example of a lost wax casting in gold is the little onager or wild ass on the rein-ring from Queen Pu-Abi's chariot, excavated in the royal cemetery at Ur and dated about 2600 B.C. (4). Again, the skilful design and execution of this casting show that considerable experience with the technique must have been built up over a fairly long period, a view supported by the elaborate nature of the miniature copper casting of a Sumerian king driving a chariot drawn by four wild asses found at Tell Agrab and attributed to a rather earlier date, around 2850 B.C. (5). Human figures, bulls' heads and 'offering stands' (complex figures made to support plates of offerings to the gods or bowls of incense) made in almost pure copper have been found in temples of the same period excavated at Khafaje, east of modern Baghdad, these showing great skills in modelling in the wax though rather imperfect casting techniques, but considering the difficulty of casting straight copper the workmanship is still astonishing (6).

Contemporary with these finds in Mesopotamia, a number of human statuettes in bronze was found some 400 kilometres away near Antioch, showing that the technique was understood in ancient Syria.

In the latter half of the third millenium B.C., metallurgy advanced more rapidly throughout the Near East and the Aegean, and processes including lost wax casting spread across a wide area although Sumerian influences remain to be seen in both technical and artistic fields. Goldsmiths and cop-

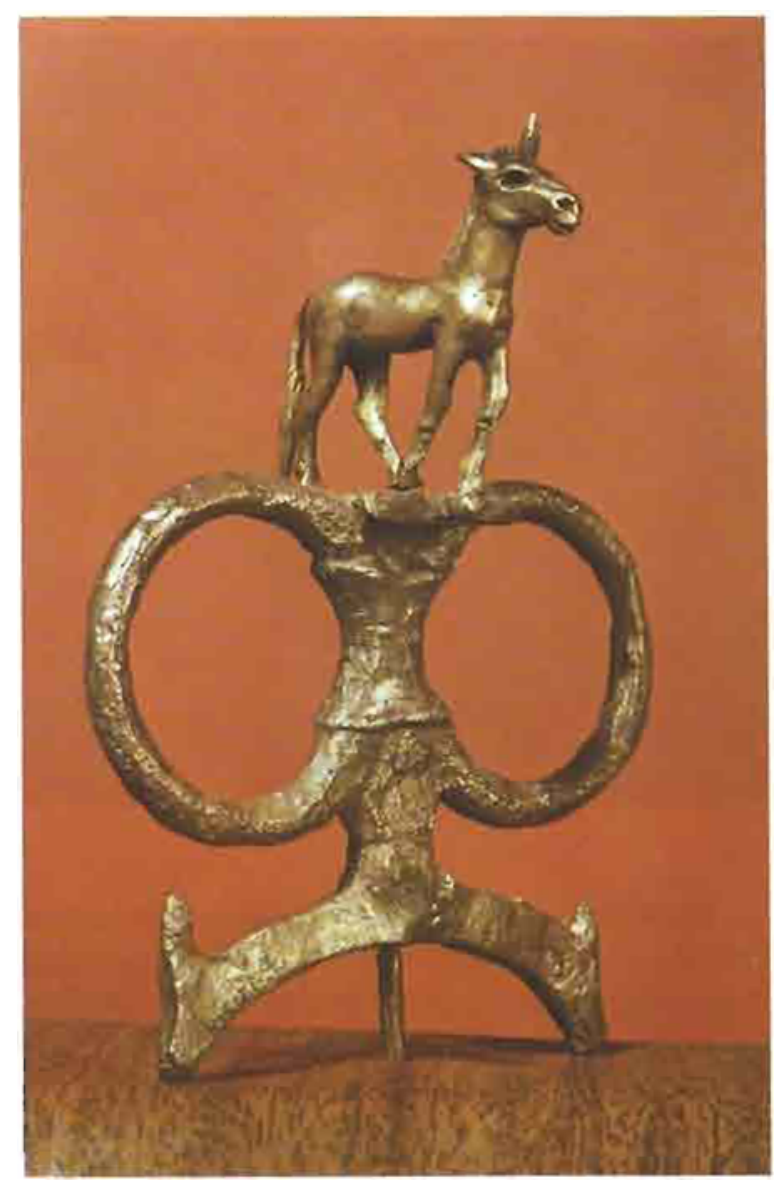

persmiths rose in importance and were increasingly patronised by local rulers and aristocracies, while astonishingly extensive trade routes were established, many of them by prospectors and miners searching for sources of metal, although some such routes had been in use for many centuries for the trade in obsidian, the glassy volcanic substance from Anatolia and elsewhere that was so valuable in making cutting tools in Stone Age times.

\section{Anatolia and Greece}

In Anatolia itself, a hoard from another so-called royal cemetery at Alaca Hüyuk, east of Ankara, excavated by Turkish archaeologists, included a number of bulls and the large copper casting of a stag - also a sacred animal of the time - most skilfully inlaid with gold and dated around 2400 B.C. (7). At another site, Horoztepe, some 150 kilometres further north east, similar finds included a larger figure of a bull solid cast in copper with muzzle, horns and ears coated with gold foil, as well as a more massive but rather more crude figure of a stag and a statuette of a woman nursing a child (8). These are thought to be a little later in date than the finds from Alaca Hüyuk, but both hoards show that the metal technology of the Pontic area in northern Turkey was highly developed, while it appears that the technique crossed 


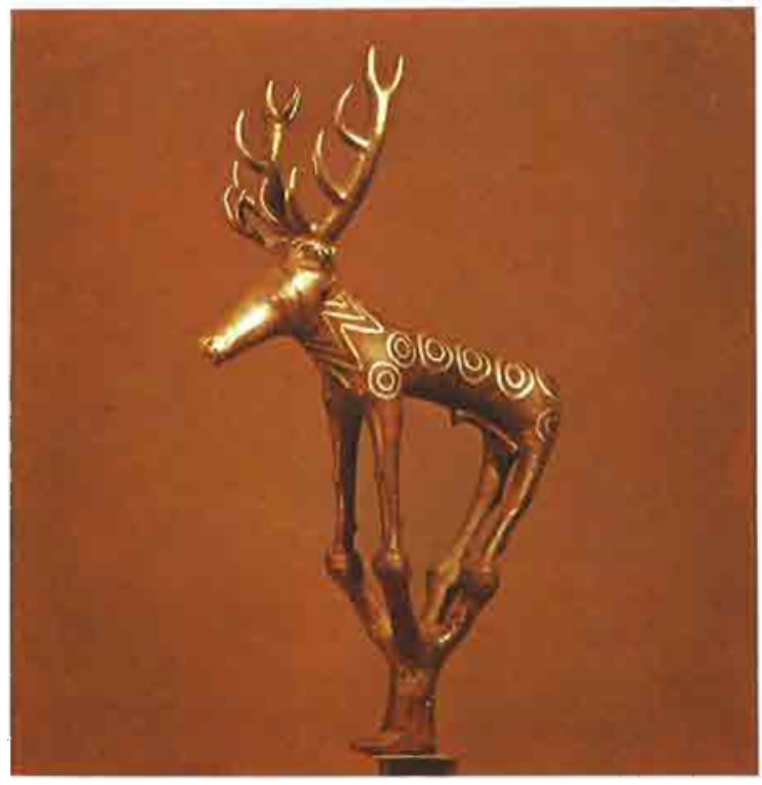

the Black Sea into Caucasia. Here again, the excavation of a great chieftain's tomb at Maikop yielded lost wax castings of bulls in both gold and silver, ascribed to around 2300 B.C. (9).

Trade, and with it the transmission of technological ideas, extended in practically all directions from Mesopotamia; eastwards, for example, as far as the Indus valley in modern Pakistan where a beautiful and well known copper casting of a dancing girl was found at Mohenjo-daro, while charming little lost wax castings of carts or chariots only 5 centimetres in height were excavated at Harappa and at Chanhudaro, other cities of the Irdus civilisation which flourished from about 2400 to 1700 B.C. (10).

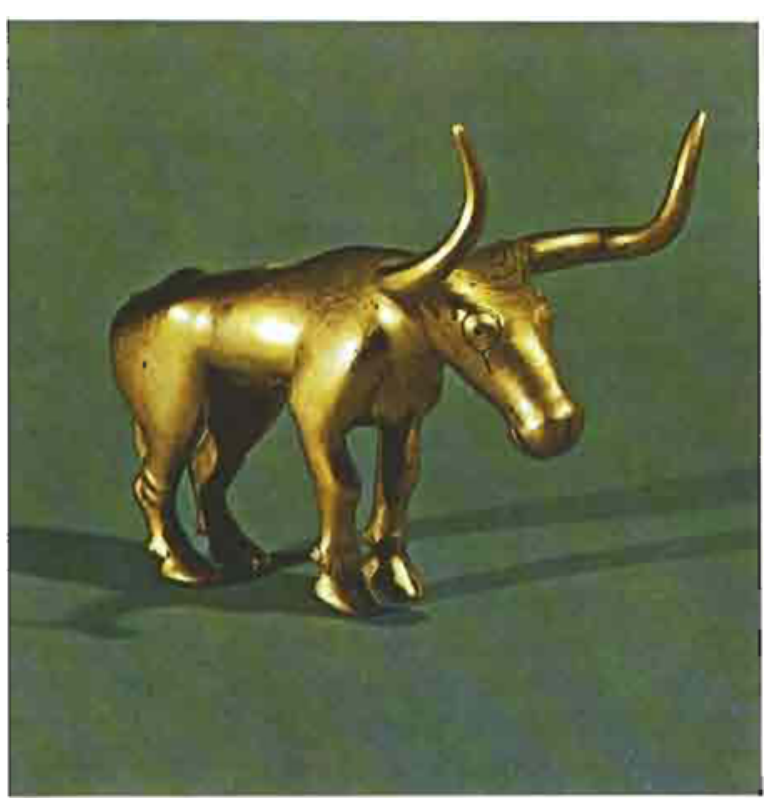

Excavation of the royal tombs of Alaca Hüyuk in Anatolia, east of Ankara, revealed a number of copper and gold objects, including this large lost wax casting of a stag, one of the sacred animals of the local culture and dating from about 2400 B.C. It is some 50 centimetres in overall height. The sprues were not removed and show clearly the method of casting, the animal head downwards. The inlaid zig zags and concentric rings of gold also show a highly developed technique of metal working

Photograph by Josephine Powell

Westwards the knowledge of metallurgy reached the Cyclades islands and Crete early in the third millenium with settlers arriving probably from Anatolia. Modest resources of copper, silver and gold existed and the simple casting and working of these metals became established. Lost wax castings of dress pins in arsenical copper, with heads in the form of flowers, jugs and double spirals have been found on the islands of Syros and Naxos and dated to around 2300 B.C. (11). In Crete, ornamental daggers in gold, as well as votive human figures in bronze, have been found at Mochlos and at Tylissos dated to about 1600 B.C. (12). At much the same time there is some evidence from mainland Greece of lost wax casting, the technique having travelled from the Cyclades. The Aegean Sea was by this time a highway for both men and ideas, and Cyprus too developed metallurgy based upon its native copper ores while statuettes of human figures lost wax cast in copper have also been found there, including a most impressive figure of an 'Ingot God', standing holding a spear, with his head raised, on an oxhide-shaped copper ingot (13).

Similarly, Egypt received some aspects of culture and technology from Mesopotamia, but was rather slow in their adoption. Most Egyptian metal working in the third millenium consisted of the hammering of gold nuggets and of copper vessels, but by about 2200 B.C. copper statuettes were being cast by the lost wax process and a number of them can be seen in museums.

So far most of the cast objects mentioned have been associated with royal tombs and their treasures or with temples and the practice of religion. The exchange of expensive gifts of this type was a feature among the rulers of the ancient world and it was a long time before increasing population, greater supplies of food and then the greater specialisation of craftsmen led to a wider production of metal objects.

This beautifully modelled figure of a bull, cast in gold by the lost wax process, is one of a pair - with two other similar figures in silver - from the framework of a canopy set up over the body of a chieftain in a tomb at Maikop in the northern Caucasus, dating from around 2300 B.C. The bull, only 6 centinetres in height, is much smaller than the Alaca Hüyuk stag, but shows a greater skill in nodelling Photograph by courtesy of the State Hermitage, Leningrad 


\section{The First Recorded Use of Lost Wax Casting}

The earliest known written reference to lost wax casting comes from the Babylonian city of Sippar and is dated 1789 B.C., during the reign of the great King Hammurabi. Written in cuneiform on a clay tablet, this is a receipt for a small quantity of wax issued to a metal worker and is composed in the typically bureaucratic manner of the period.

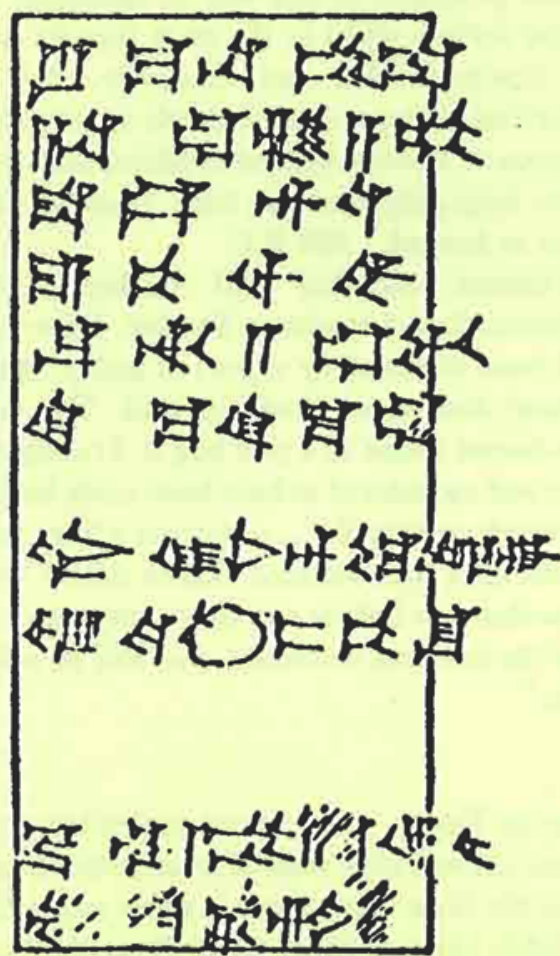

'Two thirds of a mina of wax to nake a hronze key for the temple of Shamash received by the metal worker from the temple treasury

In the presence of Silli-nin-karrak and of the storekeeper, his colleagues

On the nineteenth day of the month of Arabsammu in the year of building the temple wall'
The closing years of the third millenium and the first centuries of the second were times of great disruption and violence among all the peoples of the Near East and of widespread movements of less cultivated races. In Mesopotamia the Third Dynasty of Ur achieved stability from about 2100 until 1950 , and it is from this period that we have some of the first written records on clay tablets of the work of sculptors and goldsmiths attached to the temple organisations (14), as well as of the long and dangerous journeys undertaken by donkey caravan to seek supplies of copper and gold in Anatolia, Syria and elsewhere. Merchants from Mesopotamia established settlements in a number of Anatolian centres; the best known of these, from clay tablets describing their transactions, was at Kanesh, now Kültepe, where a market colony existed from about 2000 B.C. until 1850 for the exchange of Sumerian cereals and woven cloths for supplies of copper, gold and silver (15).

This culture did not survive, however, and it was succeeded by the Babylonian dynasty, the political centre of gravity having moved northwards up river. This lasted for three centuries, and it was the sixth of the line, Hammurabi, who reigned from 1792 until 1750 B.C., who presided over a particularly rich and productive phase of Mesopotamian history. $\mathrm{He}$ is himself shown in a delightful little casting, now in the Louvre, in an attitude of worship, but the great interest from his time arises from the first known written reference to the lost wax casting process. A clay tablet inscribed in Old Babylonian cuneiform from the holy city of Sippar records the issue, in the fourth year of Hammurabi's reign, of a quantity of wax to a metalsmith - described as a ququrrim, the first recorded name for a metal worker - for the casting of a bronze key. A transcription of the tablet and its translation are shown here (16).

Under Hammurabi's great Code of Law, a closed guild system was established for each craft, including of course goldsmithing, and a member had to be born into the guild and learn his trade from his father. Such guilds were also an important means of transmission of techniques and throughout the Near East itinerant metal workers travelled immense distances carrying with them, as we shall see later, small stone moulds in which they could fashion wax models for casting as well as supplies of metal.

Throughout the Aegean area, lost wax casting became more prevalent in the middle centuries of the second millenium. In mainland Greece, Crete and 


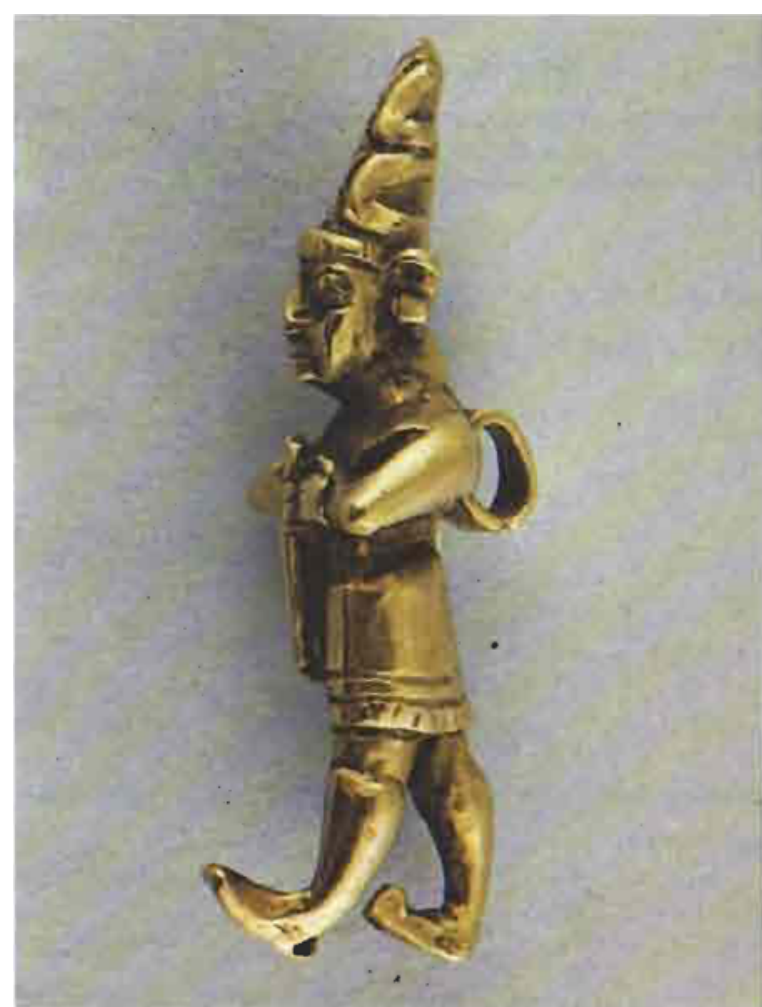

The Hittites, one of the great powers in Asia Minor from about 1800 until 1200 B.C. also developed the art of lost wax casting. This small figure of a Hittite god or king is solid cast in gold and is dated to the fourteenth century B.C. Photograph by courtesy of the Trustees of the British Museum

Cyprus, many examples of the technique have been found, mostly human and animal figures, including the inevitable bulls in Crete and a little chariot group from Cyprus, most of course cast in bronze but a number in gold. The little statuette of a Hittite king or god illustrated here dates from the fourteenth century B.C. and was solid cast in gold. A rather similar figurine in gilt bronze comes from Megiddo in Palestine, while excavations at Alalakh, west of Aleppo, have revealed the lost wax casting of gold jewellery in the fifteenth century (17).

Before this period, however, the process had made its appearance in central Europe, where a native copper metallurgy had existed since about 4000 B.C. and where ample supplies of gold were available from Transylvania. The idea of lost wax casting may possibly have arisen independently, but it may more

The technique of lost wax casting began to be practised in central Europe, probably about 2000 B.C. Earlier, in the Near East, unany hundreds of dress pins with animal, spiral or other decorated heads have been fonnd cast in bronze and in gold. This is the head of a large gold pin, 15 centimetres in lengtb, found at Trassem in the Rhineland and dating from 1600 B.C. The multi-spiral motif, executed by rolling wax into the form of wire, can be traced back before 2500 B.C. in Mesopotania

Photograph by courtesy of the Rheinisches Landesmuseum, Trier probably have been carried, along with the artistic motifs, by the established trade route up the river Danube. Gold jewellery such as brooches, fibulae, and massive torcs as well as ceremonial or symbolic weapons decorated with geometric designs carved in the wax were produced in this way in Romania, for example, and further afield in the areas that are now Hungary, Czechoslovakia and Germany. An interesting survival of the ancient multiple spiral motif, once a religious or fertility symbol in Mesopotamia, is shown in the large gold dress pin from Trassem, near Trier, dated to around 1600 B.C.

The technique travelled still further north, reaching Denmark and southern Sweden. Here prosperity had been achieved by export of amber to the Mediterranean and return trade in gold. The well known sun chariot found in a peat bog at Trundholm in Denmark and considered to have been made locally in the fourteenth century B.C., comprises a large gold disc mounted on a four-wheeled chariot drawn by a bronze horse that was hollow cast over a clay core - a variation of the lost wax technique that will be referred to again.

\section{Egypt}

To return to Egypt, where metal technology was for long more conservative than in Mesopotamia and elsewhere in the Near East, there is every indication of a remarkable burst of inventive skills in the New Kingdom period, beginning in 1559 B.C. Lost wax casting, possibly re-introduced by immigrant craftsmen, became much more evident for the making of massive gold signet rings, parts of great gold pectorals and statuettes. The little figure of Amenophis III (1 405-1 367 B.C.) illustrated here was cast in solid gold. It was suspended by a chain for use as a pen-

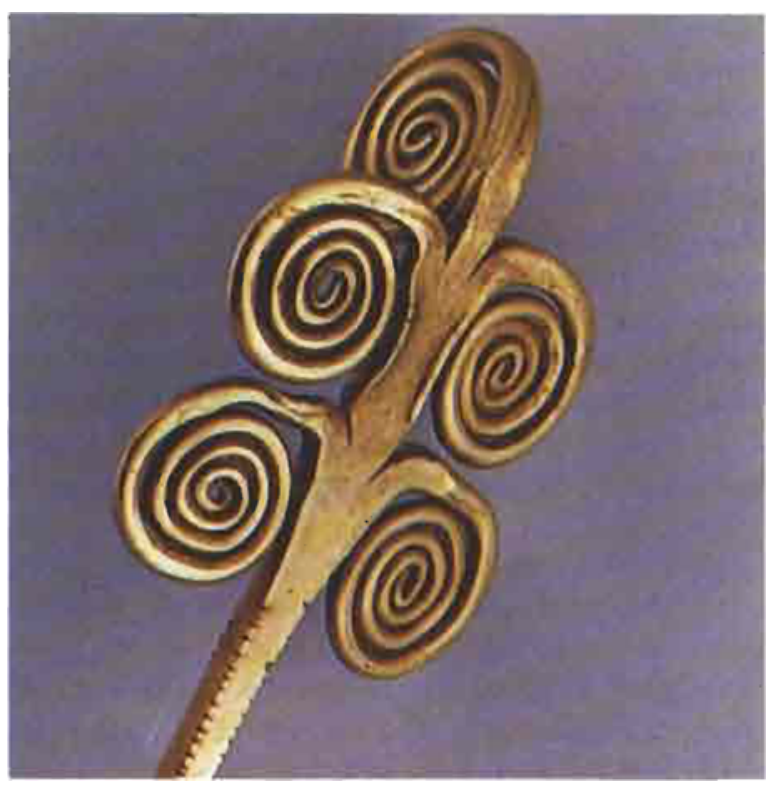




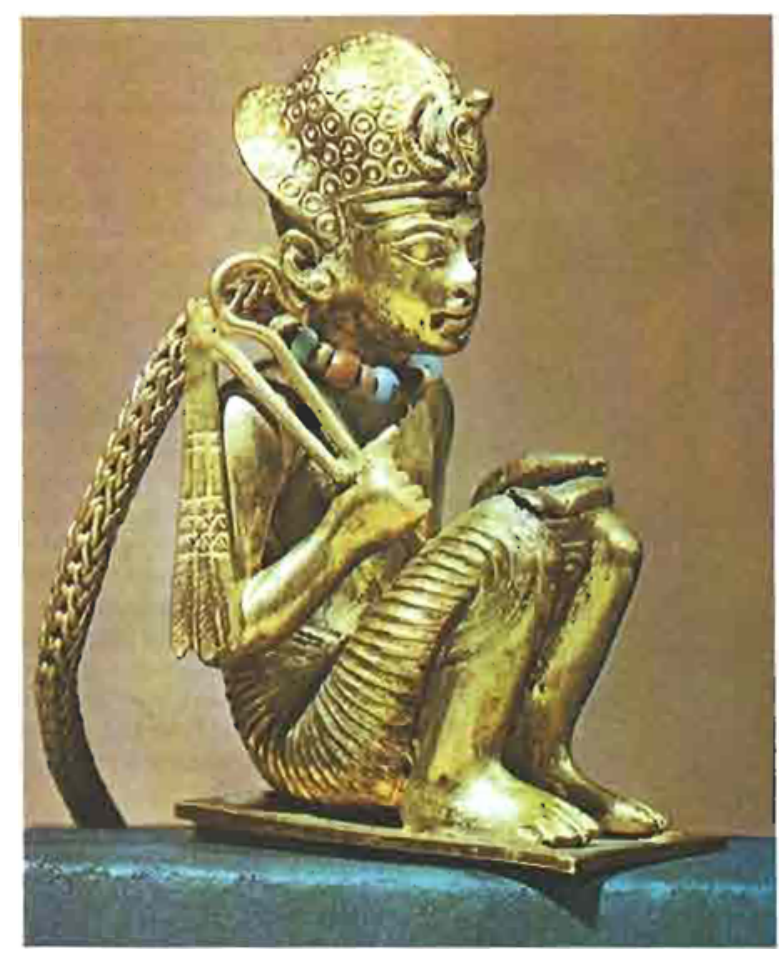

dant, and shows a further development in the process, the attaching of items made from wire or strip to the basic casting. Probably the best known, and certainly the most photographed, lost wax castings from this period must be the solid gold figures of the vulture goddess Nekhbet and the uraeus or cobra of Buto that decorate the forehead of the great funerary mask of Tutankhamun.

In the twelfth century B.C., another period of crises and upheavals set in across the whole of the Near East and Aegean, similar in many respects to that of a thousand years earlier. Egypt was invaded, the Hittite empire collapsed, as did the Mycenaean civilisation, and nomadic peoples overran large areas of the ancient world. Several centuries of 'Dark Ages' followed, during which patronage for metal workers would have been minimal although it is likely that their skills survived from generation to generation. Probably such craftsmen migrated westwards through the Greek islands and even to Etruria.

\section{The Phoenicians}

Recovery eventually came in the ninth century. By this time, the Phoenicians had assumed the maritime power of the Myceneans and had developed their trading and colonising activities throughout the Mediterranean. Their craftsmen produced great numbers of figurines in bronze by lost wax casting, many of them however of indifferent quality, and also items of gold jewellery by the same technique.

Phoenician colonies established in Sardinia, Sicily and in the Balearic islands have yielded many finds of
Egypt was slow in adopting the lost wax process, and very little evidence is to be found of its use before abont 2200 B.C. However, by the fourteenth century great progress was made and the idea had developed of attaching decorative pieces to the basic easting. This small figurine of Amenophis III, only 5 centimetres in height, is solid cast in gold

Photograph by F.L. Kenett

bronze statuettes of warriors and chieftains. In Sardinia in particular, these show a highly developed skill in modelling the wax, with every figure slightly different in design.

Greece, by 800 B.C., had also re-established itself and resumed contacts with its eastern neighbours. The casting of gold is in evidence, possibly undertaken by Phoenician craftsmen who settled in Greek cities and engaged local workmen, while in Corinth in particular, excavations have disclosed a considerable centre of lost wax casting, more devoted to bronze statuettes (18).

In Asia Minor, the Hittites were succeeded by Phrygians and by the kingdom of Urartu in the area around lake $V$ an and in this latter region a high quality of metal working developed during the seventh century. One characteristic feature consisted of cast bronzes in the form of animal heads, many of them gilt, for attachment to cauldrons and other vessels, a development that spread widely into European styles.

Both bronze workers and goldsmiths in this rather remote region displayed great skill and workmanship, and when their religious centre Musasir was sacked by the Assyrians in 714 B.C., immense quantities of gold jewellery including cast earrings were removed, as well as many bronze figures including one of a bull and another of a cow with its calf, all said to have been cast in the temple foundry. At the same time, many of these metal workers and goldsmiths were taken back to Assyria - a calculated procedure often adopted by the Assyrians who habitually removed craftsmen from conquered areas to their own cities of Assur, Nimrud and Nineveh, where they forced them to exercise their skills.

\section{The Animal Art of the Scythians}

Urartu was later invaded, however, by Cimmerians from the Caucasus and then by the Scythians from the steppes of southern Russia. These nomadic peoples had already developed a metal working and artistic culture in their homeland, and many of their creations, lost wax cast in gold and most of them associated with the horse and its trappings, have been found in Siberia and are now displayed in the Hermitage Museum in Leningrad. The example illustrated here, typical of their so-called 'animal art', is a belt plaque in the form of a tiger or leopard coiled into a semi-circle (19). This distinctive style, together with its means of representation by lost wax casting, 


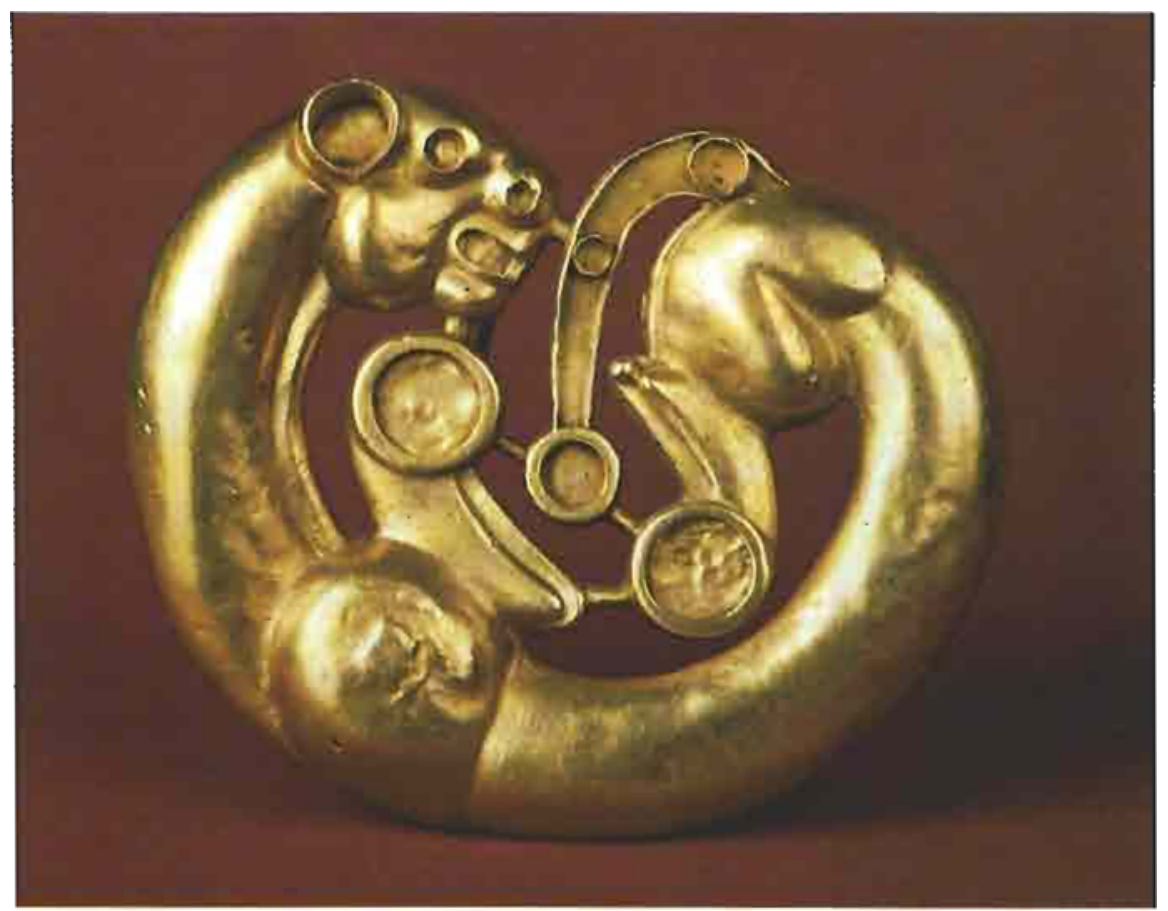

Many large lost wax castings in gold liave been found in Siberia nude by the Scythians, a nonıadic people ranging over the steppes between the seventh and the third centuries B.C. Most of these were for harness decoration or belt buckles and they usually depict a distinctive animal style of art. This elegant piece, measuring 11 by 9 centimetres, from the collection formed by Peter the Great and now in the Hernitage Museum in Leningrad, dates from the fourth century and shows a coiled tiger, a motif that probably originated further to the east in the Altai Mountains. The wax model was most probably made in a mould of wood, in the use of which these people were also highly skilled

seems to have originated in the Altai mountains of central Asia in the seventh or sixth century B.C. and to have been transmitted both westwards to the Scythians and eastwards via the Ordos region to China by the Hsiung-Nu, a nomadic people of the eastern steppes of Inner Mongolia. Lost wax casting was thus introduced rather belatedly to China in the fourth century B.C., the bronzes of earlier periods having been cast in highly complex piece moulds (20).

Animal art, and particularly the making of horse bits and other pieces of harness, played an important role in several areas of western Asia. During the ninth to the seventh century B.C., an exceptionally varied and unique range of castings in bronze was produced in the Luristan province of western Iran along the mountain frontier with Iraq. Some of the less decorated objects were cast in two-piece moulds, but the more characteristic and elaborate items were made by the lost wax process; these included cheek pieces for horse bits representing animals such as bulls, lions and boars as well as mythological beasts like the sphinx, the chimaera and the griffin, and a range of finials or cult symbols with heraldic groups of rampant animals (21). Heavy dress pins and decorated bracelets with animal heads were also cast in gold by these people. Although there had been a

This large gold beaker, found in an Etruscan tomb and dated about 670 B.C., is made from sheet gold hut the rin is decorated with four small lost wax castings of sphinxes. It is now in the Etruscan Museum in the Villa Guilia in Rome. This technique of decoration is also found in later centuries in the Celtic regions of Europe

Photograph by Michael Holford simple copper industry in Luristan for many centuries, it seems that this particularly splendid phase of lost wax casting was a local enterprise to serve a warrior aristocracy in a style suited to its needs. It declined by the end of the seventh century, probably because of the increasing power of the Medes and Persians who severed the links with sources of metal.

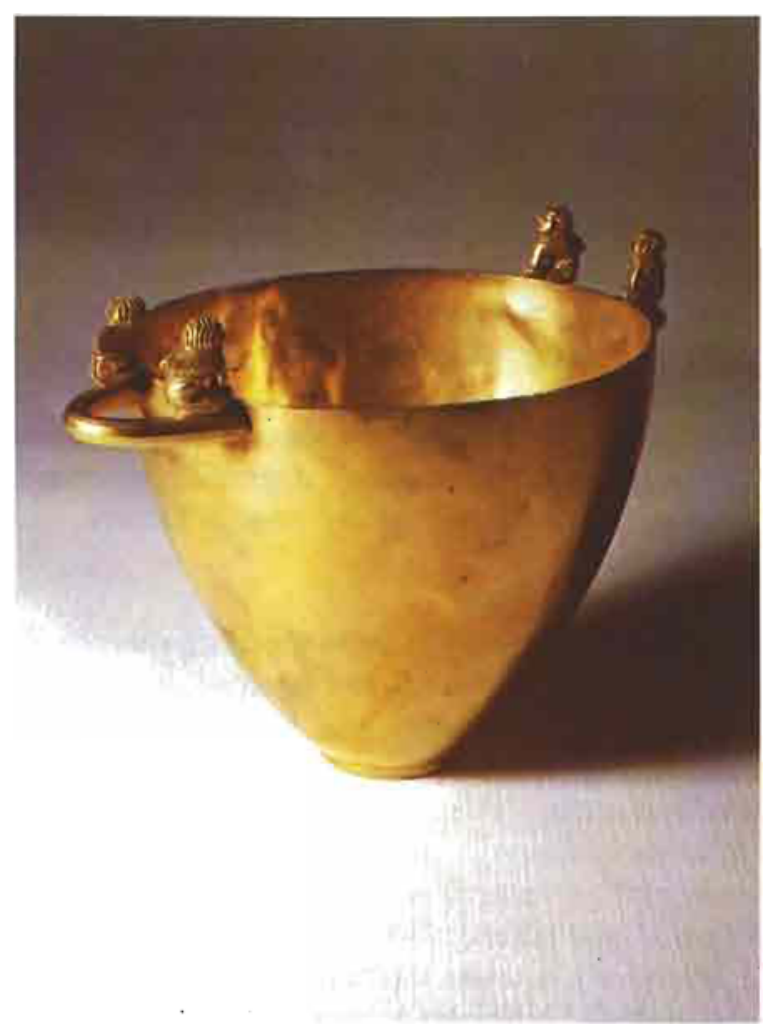




\section{The Skill of the Etruscans}

At about the same time as Luristan had shown such vigorous activity another spectacular development occurred in Europe - that of the extraordinary skill in metal working of the Etruscans. The origins of these people are still somewhat obscure, but it is generally considered that their ancestors arrived from Anatolia over a period during the eighth century B.C. or even earlier, settling in the west central region of Italy now known as Tuscany and mixing with local inhabitants, and bringing with them expertise in both mining and metal working.

City-states were established, and extensive trading with the Greeks and Phoenicians brought in many bronze and gold luxury objects which the Etruscans began to copy and later to improve or modify in their own characteristic style. Copper was readily available and gold could be obtained from Anatolia or closer to hand from Ischia. Excavation of their tombs has disclosed great riches of utensils, votive figures and jewellery of outstanding workmanship. Among these are large bowls and massive cauldrons beaten from sheet but with feet, handles and animal and human figures attached to them that were solid cast by the lost wax process. By about 600 B.C., the Etruscans had solved the problem of hollow casting, using wax modelled over a clay core. A delightful little bronze statuette of a girl and the head of a young man, both showing the remains of the clay core through cracks in the castings, and a pair of griffins' heads from Perugia, also for mounting on a cauldron, reveal the use of this method of manufacture (22). A remarkable gold beaker found at Palestrina - ancient Praeneste - in a tomb dated about 670 B.C., has four small animal figures, solid cast in gold, soldered around the rim (23), a style of decoration much employed by the Etruscans and one that spread northwards into central Europe first by importation of this type of vessel across the Alps and then by local production.

\section{The Celtic Tribes}

In this latter region a considerable increase in population was taking place in the first millenium B.C. with great movements of people along the main rivers. Celtic speaking tribes expanded fairly rapidly, came into contact with the Mediterranean world and with the Scythians from southern Russia who migrated into eastern Europe and both were to have an influence on Celtic art and craftsmanship in metal. A gold stag, found at Zöldhalompuszta in Hungary and now in the National Museum in Budapest, is but one example of Scythian penetration westwards (24).

The making of bridle-bits and other horse harness had for long played an important part in the history of lost wax casting, and from about 800 B.C. many new designs began to appear throughout Europe. These, and artifacts discovered in excavations, show the Scythian influence from the east, while the establishment of the Greek colony of Massalia - modern Marseilles - in 600 B.C., greatly increased contacts with the Greek world.

Celtic metal working achieved a very high standard and was much encouraged by local chieftains. Archaeologists distinguish between two stages of development: the Hallstatt phase, named after a cemetery in Austria and extending from around 750 to 500 B.C., followed by the La Tène culture, named after a lake dwelling in Switzerland, lasting from then until the time of the Roman conquests. From the earlier period, some exciting examples of lost wax castings have been found in elaborate burials. They include a detailed bronze model of a ritual vehicle with figures representing immolated warriors, horses and sacred beasts surrounding a goddess holding up the bowl of the sky, excavated near Graz in Austria and dated to the sixth century. But another major influence on metal working arose from the trade in wine developing up the Rhone valley which brought about the importation of Greek and Etruscan vessels for its storage, serving and drinking. The Celts, in fact, developed a great love for the wines of the south and soon began to produce copies of these vessels in their own distinctive style; large bronze flagons and cups were decorated, like the Etruscan beaker mentioned above, with beautifully modelled animal or equestrian figures made by lost wax casting and attached to the vessel either in the form of handles or simply as decoration. One distinguished archaeologist, writing of this period, recorded his opinion that 'the La Tène art may largely have owed its existence to Celtic thirst' (25).

The most interesting articles of gold from Celtic times are, however, the great torcs or neck rings that have been found in many parts of Europe, including Britain. These were made of twisted bar or heavy wire, but their decorated terminals were very often cast directly onto the ends by a modification of the lost wax process. The torc illustrated here, one of six found near Ipswich in England and dated to the first century B.C., was the object of an investigation and reconstruction some years ago and was clearly demonstrated to have been made in this way, the decoration having been tooled in the wax model (26).

\section{Variations on the Basic Method}

The time has come to interrupt the historical account of lost wax casting in order to review the technique itself and the several variations that were developed over the centuries.

The earliest craftsmen no doubt learnt by trial and error the need to provide adequate runners or sprues, also made of wax, to allow the molten metal to flow 


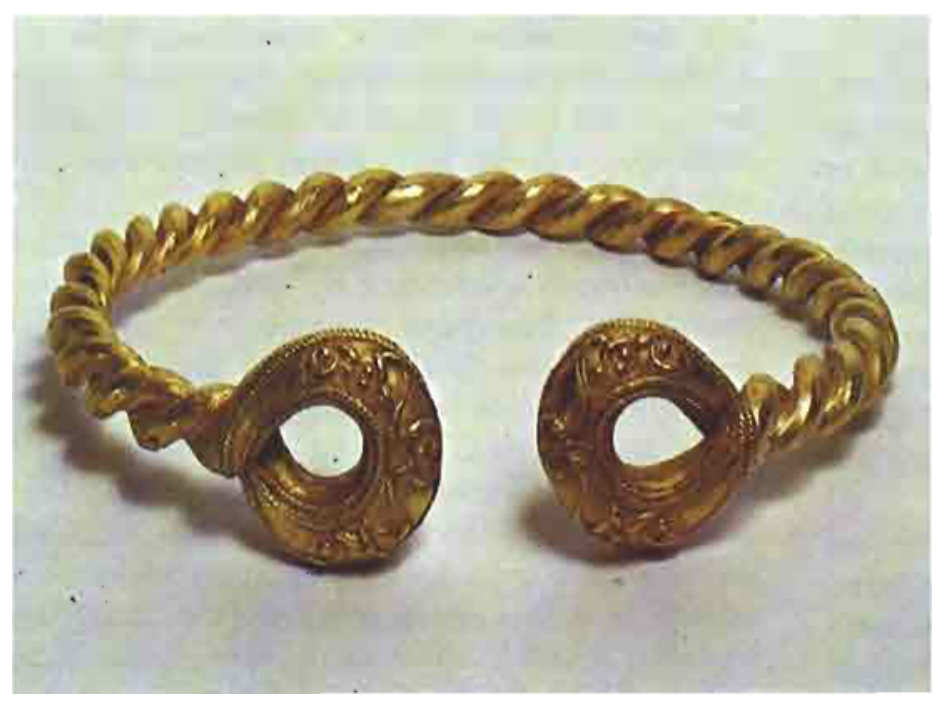

Both the wealth and the cralismanship of the Celtic tribes in England prior to the Roman conquest were displayed in the massive gold tores or neck rings worn by their chieftains or possibly used as large items ol currency. This is one of six similar tores found at Ipswich in East Anglia, formed from twisted wire but with the decorated terminals cast onto the ends by the lost wax proeess. Undoubtedly this was the type of neck ring worn by Boudicen, the queen of the Iceni who Ied the revolt against the Ronnans in 60 A.D. The Roman historian Cassium Dio described her formidable appearance:

She was huge of frame, terrifying of aspect, and with a harsh voice. A great mass of bright red hair lell to her knees: she wore a great twisted gold necklace and a tunic of nutuy colours."

Pholograph by courtesy of the Trustees of the Britisl Museun

readily into the mould. These were usually attached to the bottom of the model to be cast. The metal smith would also have had to make suitable risers for the escape of air when the metal was poured in, although by choosing a mixture of fresh clay with sand, charcoal or ground up pieces of fired clay he was soon able to construct a mould sufficiently porous to allow for this. Naturally, all these runners and risers were cut off and put back into the melting pot, although in a few cases they have been left in position, as is shown on the stag from Alaca Hüyuk illustrated on page 66 .

\section{Hollow Casting}

The early objects made in this way were cast solid, and if cast in gold would be expensive, but by about the middle of the second millenium B.C. a technique for hollow casting had been developed in the Near East, which spread slowly to Greece, Etruria and elsewhere. A clay core was first made and fired; this was then covered with a layer of wax as thick as the desired wall thickness of the casting and all the detail was carved or modelled on this layer. After coating with clay and firing to harden the mould and to melt out the wax, molten metal was poured into the cavity as before. In order to retain the core in its correct position, small nails or pieces of wire were first driven through the layer of wax, protruding into the outer coating of clay. Generally, the core was removed from the finished casting, but as mentioned above in describing the sun chariot from Denmark, in many cases remnants of it are still in position. Sometimes the heads of the pins or chaplets can also be seen on the surface of the castings.

\section{Indirect Casting}

These two methods are known as direct lost wax casting. A different technique, known as indirect casting, was to take a model in any material such as stone or wood, to form a mould, probably in several pieces, made of clay or some other plastic material, and then to coat the inner surfaces with a thick layer of wax by painting or brushing in several applications. This method had the advantage that much larger castings could be produced, and it is in fact the procedure still used today in producing bronze or gold statuettes.

\section{Moulds for Wax Models}

The many advantages of lost wax casting as a means of making fairly elaborate objects were accompanied, however, by one major disadvantage - it was a oneoff process. Obviously the carefully shaped wax model was destroyed by melting, while the clay mould had to be broken up to release the casting. It must have occurred to early metal smiths that a great increase in productivity could be achieved if wax models could be readily made in quantity and this is confirmed by the finding of a number of small and easily portable moulds made in steatite or mica schist. At one time archaeologists believed that these were used for the actual casting of gold or bronze, but several such moulds examined by the writer show no trace whatever of their having been in contact with molten metal. The two stone moulds illustrated here, one from ancient Sippar in Babylonia, dated about 1700 B.C. and the other from Nimrud, with an eighth century B.C. dating, show clearly how molten wax could be poured into the cavities and could then easily be trimmed to final shape. Almost identical moulds for gold jewellery were found, for instance, by Heinrich Schliemann during his famous excavation of Troy (27) and by Sir Leonard Woolley at Alalakh (28), while others were described by Canby as having been carried by an itinerant goldsmith travelling the trade routes linking Anatolia with Mesopotamia (29). 
In several regions of the Near East small portable moulds made of stentite or other types of stone have been found witl nmmerous designs of jewellery carved into them, occasionally on more than one side. These have sometimes been ascribed to the actual casting of trinkets, but they seldom show signs of having been in contact wilh molten metal and they were more probably carved by itinerant smiths for pouring beeswax to make their models for lost wax casting. These two examples from a number in the possession of the British Museum show, on the left, a mould from ancient Sippar in Babylonia dated to about 1700 B.C. and, on the right, one from Nimurud in Assyria dated to the eighth century B.C.

Photograph by courtesy of the Trustees of the British Museum
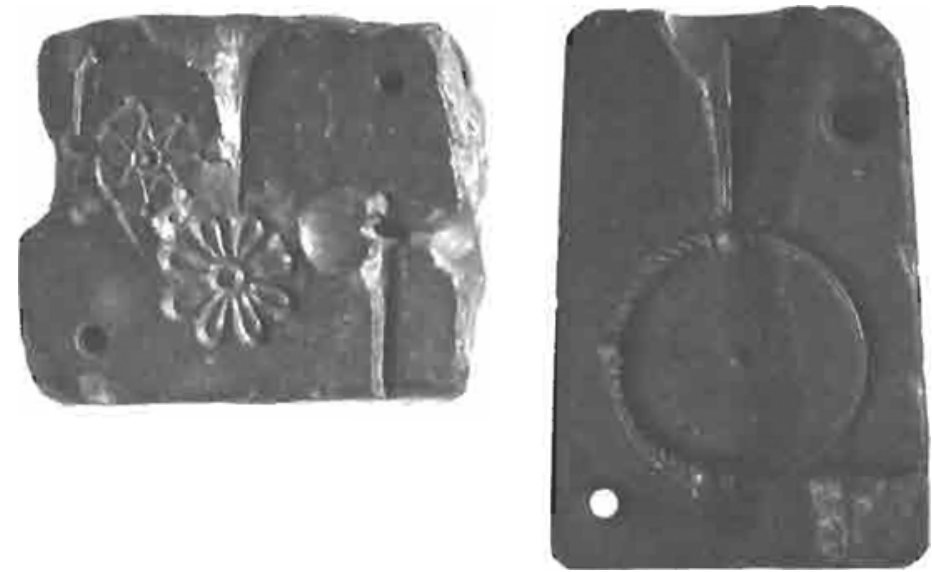

Bronze moulds have also been found and ascribed to the direct casting of metal, but again more recent views lean towards their use for the casting of wax models or sometimes for lead patterns - the "lost lead'variation of the process (30).

The use of wooden moulds for the preparation of wax models also seems to have been likely. An example is the Scythian gold tiger or leopard illustrated on page 70. (A bronze counterpart of this, identical in design, but almost twice the size, is in a private collection in America (31)). Scythian animal art was also expressed in wooden carvings, and it is probable that the original patterns for casting were produced in wood.

\section{Casting-On}

Another development of the basic lost wax casting was the 'casting-on' of parts of an object. By the time that the Iron Age had arrived and when iron daggers and swords were being produced it was apparently the custom to provide a bronze - or sometimes a silver or a gold - hilt to these weapons. This was achieved by making a wax model to surround the tang, covering this with clay in the usual manner, and then pouring the molten metal into the cavity left by the melted wax. If this was carried out with care and if the iron blade had been well cleaned, a metallic bond would be obtained between blade and hilt, but in a number of cases there is evidence of a thin oxidised layer between the two (32). The large Celtic gold torc illustrated on page 72 gives another excellent example of this casting-on technique.

\section{Cloth Impressions}

The presence on the backs of some objects of clear impressions of woven cloth has puzzled archacologists for a long time, but one reasonable explanation has been put forward by Joseph Ternbach, of the University of Pennsylvania Museum, with particular reference to the Scythian gold plaques (33). Some, but not all, of these show a positive impression of coarse fabric such as canvas or linen and the conclusion is that, because of their design containing so much openwork, the wax model would have been fragile and difficult to remove from a mould and therefore a cloth support, cut to the same design, was placed on the layer of wax and united with it by pressure. With this re-enforcement the wax model could then be more readily removed from the mould and the finishing touches and details applied. Then, in the course of melting out the wax and firing the mould, the fabric would have burnt away, leaving its impression on the back of the casting.

An alternative explanation, related to much later castings of the Viking period, found in Scandanavia and in Scotland, was offered by Oldeberg (34). This supposes that a wax model was built on a layer of clay upon which a piece of cloth had first been laid, this piece of clay forming part of the final mould.

These cloth impressions are positive on the casting. Cloth impressions on moulds are very much more rare, as very few mould fragments have ever been identified. However, an Iron Age bronze foundry of about the first century B.C. excavated at Gussage All Saints in the west of England yielded many thousands of mould fragments (35). All the moulds were used to cast bronze harness pieces or chariot fittings by the lost wax process, most of them elaborately decorated. A detailed study of these mould fragments recently undertaken at the British Museum (36) has revealed not only finger marks on the outer surfaces where hand finishing of the mould had been carried out and the impressions of wood grain from a master mould for the wax model, but also the impressions in relief of loosely woven cloth of rather poor quality such as hessian or sacking. These were apparent only on the centre link castings of three-piece articulated bridle bits, and it is considered that after the side links had been cast, the centre link was modelled in wax, but in order to keep the pieces apart, cloth was then wound around the side links before investing the three pieces with clay, so creating a positive impression of fabric on the inner surface of the mould. 
So, by the beginning of the Christian era, lost wax casting in its several variations had become well known and established throughout the earlier civilisations of the world. It was to spread, of course, both by transmission of the idea and by independent invention, to many other regions.

The Roman conquest of Greece brought an end to the invaders' disapproval of gold jewellery and opened the way for their exploitation of Greek craftsmen, particularly those working in Antioch and Alexandria, although Rome itself also became a centre of operation for immigrant Greek craftsmen. Earrings with cast pendants of small figures of gods such as Eros were very popular as also were massive gold fibulae cast by the lost wax process.

\section{Lost Wax Casting in India}

Greek designs and craftsmanship also had a major influence in India, arising from the settlement in Bactria after the conquest by Alexander the Great. Gold jewellery found in the city of Taxilia and dating from the first century A.D., shows the use of both solid and hollow casting, while stone moulds similar to those described earlier were also found (37). In the course of time, Indian craftsmen adopted the lost wax process most extensively in the production of statuettes of the Buddha, a practice that has continued down to the present day. This reached its height, however, in the Gupta period beginning in the fourth century A.D. when many exquisitely designed castings were produced for the adornment of the temples. There are several references to lost wax casting in some of the ancient manuscripts. In the Manasara Silpasastra, for example, a practical manual on architecture and sculpture compiled in about 500 A.D., there is a reasonably detailed description of the process (38):

'The craftsman should first prepare the image, complete with all the limbs, yellowish in colour, beautiful to look at and with weapons and arms as prescribed.

After placing the wax tubes on the back, on the shoulders and on the neck or the crown he should besmear the image with fine clay.... The first layer should be transparent and thin and should be dried in shade. After two days a second layer should again be applied.... The craftsman should first measure the wax of the image, which has to be made either in brass or copper or silver or gold. Brass and copper should be taken ten times that of wax, silver twelve times and gold sixteen.... Next one should melt away the wax by heating in the fire and should afterwards heat the crucible in cinders.... After carefully tilting the crucible, held tightly by the tongs, one should pour molten metal into the mouth of the tube in a continuous stream and stop when it is full to the brim of the tube.... When the image gets naturally cool the craftsman should break up the clay mould very carefully.

Then the metal image verily resembles that in wax, endowed with similar limbs and other details.'

\section{The Early Middle Ages}

Returning to the European scene, there is ample evidence that despite the repressive influence of the Romans, Celtic art and metal work persisted for many centuries, particularly in Ireland where there were plentiful resources of gold. The more primitive process of making brooches by hammering sheet gold was replaced by lost wax casting well before the Christian era, giving much more substantial pieces of jewellery, while torcs, dress fasteners and pins were made by this method. Steatite moulds have also been found, similar to those already illustrated, with provision for making a number of different wax models on several sides.

Later, in the earlier centuries A.D., two variants of the process appeared (39). One consisted of pressing a sheet of wax into a mould made of bone prior to investing with clay and casting. Many such pieces of bone have been discovered in Ireland, with small panels of decoration carved in relief, that were almost certainly used in this way. One characteristic example is illustrated here.

The other device, also found in Anglo-Saxon England and later in the Viking period both there and in Scandinavia, consisted of cutting deep depressions of inverted pyramid shape into the wax model so that

Intricately carved designs in relief on pieces of bone have been found in both royal households and monastic sites, particularly in Ireland, dating from the early centuries of the Christian era. The perfection of detail on many of them suggests their use for inpressing designs on wax models before these were invested with clay. This example comes from Lagore, a royal residence in County Meath, in Ireland, occupied from the seventh to the tenth century

Photograph by courtesy of the National Museum of Ireland

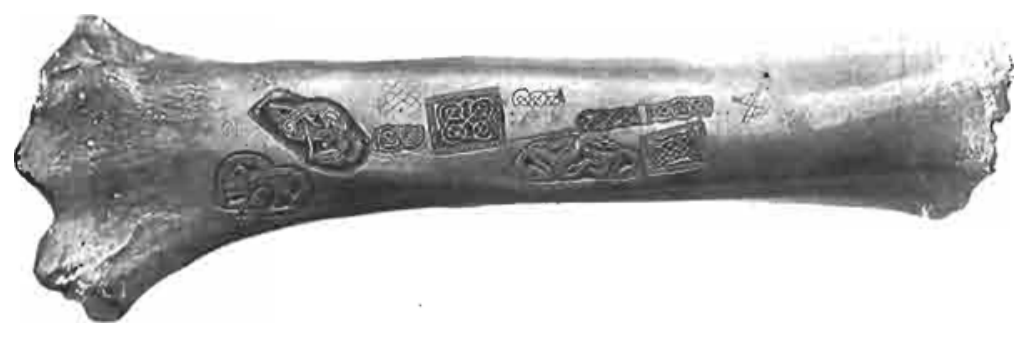


the eventual casting would glitter in the light. This technique, deriving initially from wood working and described by archaeologists as 'chip carving', appears to have originated in the eastern Mediterranean area, to have been adopted for military fittings by the Romans and then to have spread from Gaul and elsewhere in central Europe to Britain and Ireland. It was used down to the eighth century A.D. (40).

The widespread use of large and elaborate brooches of both bronze and gold, often worn in pairs, throughout northern Gaul, among the Germanic tribes and in Scandinavia and Britain in the early medieval period, led to the establishment of a number of workshops in political centres in addition to the activities of itinerant craftsmen. These highly decorated pieces of jewellery were made either by the traditional method of lost wax casting or by a modification that consisted of impressing the wax - or sometimes possibly lead - models into a piece of soft clay that was to form the upper half of a two-piece mould. Then the clay to form the lower half of the mould would be applied, the wax or lead model melted out and the complete mould fired ready for casting (41). Both the Viking and the Anglo-Saxon craftsmen, closely allied in their designs, achieved an extremely high standard of workmanship, the brooches and other forms of jewellery being decorated with animal designs and 'chip carving'.

\section{The Influence of the Monasteries}

Other than these objects of secular jewellery, much ornamental metal work such as chalices and reliquaries was produced in workshops attached to the monasteries established throughout Europe in the early Middle Ages. In these communities, skilled metal workers could readily find employment. One of the earliest to be founded was at Nendrum in County Down in Ireland and here excavation of the ruins - it was destroyed by Viking raiders in the late tenth century - has produced crucibles, moulds and carved pieces of bone such as those already described for the application of decorative motifs to wax models.

By the twelfth century a rich style of ornamental metal work had developed in the monasteries, which had become increasingly wealthy, and from one Benedictine house in Germany comes the first really detailed description of the whole process of lost wax casting. This was written by a monk using the Byzantine nom-de-plume of Theophilus, who has been almost certainly identified as a metal worker named Roger of Helmarshausen whose skilful craftsmanship is represented by two portable altars preserved in Paderborn and a heavily jewelled book cover in Nürnberg (42). His manuscript was written between the years 1110 and 1140 and leaves no doubt that he was himself a practical metal smith who thoroughly en-

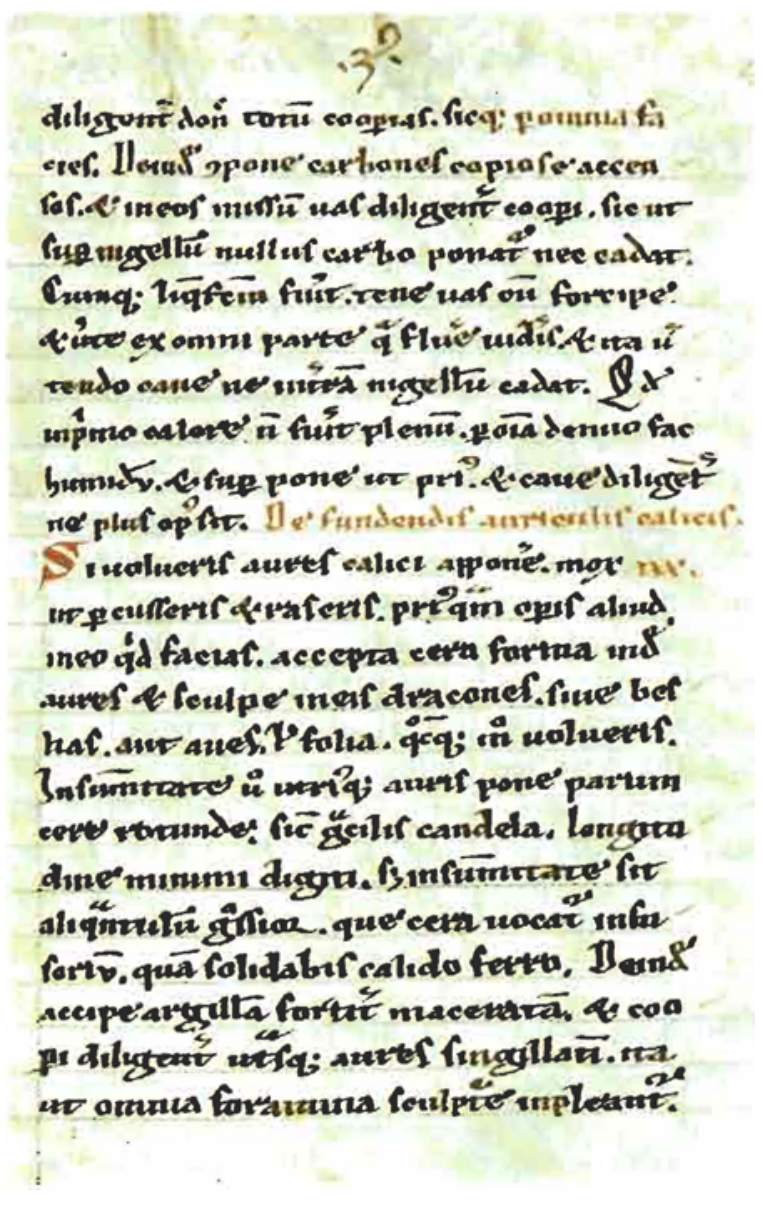

The earliest detailed and worknuanlike description of lost wax casting is that given by the Gernan monk writing under the pseudonym of Theophilus in the early part of the twelfth century. In his De Diversis Artibus, Book III, Chapter 30, he describes the casting of the handles for a large silver chalice. The account could have been written only by a practising craftsman. This page, from an early thirteenth century manuscript in the British Library, shows the early part of Chapter 30, beginning half way down with the heading in red, 'De fundendis auriculis calicis', and reads:

'If you want to fix handles on the chalice, as soon as you have beaten and scraped it and before doing any other work on it, take some wax and form handles from it and carve on them snakes, animals, birds or foliage in any way you wish. On the top of each handle put a small piece of wax, rounded like a slender candle as long as your little finger but rather thicker at the top. This is called the sprue and you should join it with a hot iron. Then take some well kneaded clay and carefully cover each handle separately so that all the hollows of the modelling are filled.'

The following page gives instructions for drying the moulds, melting out the wax, taking them from the fire and pouring the netal into the holes from which the wax has been melted out

Photograph from Harley M.S. 3915, folio 49A, by courtesy of the British Library

joyed producing beautiful objects. The illustration here shows the first part of his instructions for casting the handles for a silver chalice by the lost wax process, while a later chapter goes into the details of the 
hollow casting of a large censer, and the preparation of a sheet of wax to be applied to the clay core.

In this same century, the requirements from monasteries, abbeys and cathedrals for ecclesiastical metal work increased considerably and examples of altar candlesticks appeared in Germany, France, Belgium and England, cast in parts by the lost wax process and assembled by means of iron rods. One of the most famous of these is the Gloucester candlestick in the Victoria and Albert Museum in London. Over 50 centimetres in height, it is one of a pair, its fellow having been lost many centuries ago. It is made in richly gilt bronze in three parts, the bottom and middle sections being marked with crosses to indicate the correct method of assembly. The upper end of the iron rod that holds them together serves as the pricket for the candle, and the prolific decoration shows animal and human figures clambering among foliage, with the three feet in the form of dragons. It was presented to Gloucester cathedral soon after the Norman conquest, as an inscription records, by Abbot Peter who was elected to his office in 1104 and died in 1113 (43).

\section{The Renaissance Goldsmiths}

The beginning of the Italian Renaissance in Florence in the late fourteenth century - and its spreading northwards - revived the classical concept of rendering the human form in stone, marble or metal. A goldsmith, Lorenzo Ghiberti, followed by Donatello, led the change by the making of small freestanding statuettes in bronze in about 1425 and these very soon became treasured items for collectors and later under the Medici's became much used as diplomatic gifts. There were, of course, many other skilled metal workers and sculptors in this great period, among them Andrea Briosco Riccio who practised first as a goldsmith, Bertoldo, a pupil of Donatello to whom Michelangelo was later apprenticed, and Andrea del Verocchio, the goldsmith who became the teacher of Leonardo da Vinci.

Derived mainly from the full scale sculpture of Greece and Rome, Renaissance figures, whether displaying the human form, grotesque monsters or equestrians, mostly in bronze but occasionally in gold, were all produced by the lost wax process. In the early years of the period they were cast solid, the most satisfactory means of securing an accurate reproduction of the wax model, but one of course that destroys the original. From about the third quarter of the fifteenth century, the indirect method was applied: a multi-piece plaster mould was made around the artist's wax model, taken apart and then employed to make a second wax for casting, leaving the plaster mould for use over and over again. Later still, a layer of wax was applied to a clay model of the statuette of the thickness required in the finished casting and the details modelled on this layer.

In each case, considerable finishing work was needed, first to remove the 'cage' of runners and risers and then to complete the detail by filing and chiselling and to give a final polish (44).

In the later Renaissance, the name of Benvenuto Cellini is of course pre-eminent and in the pages of his 'Treatise on Goldsmithing and Sculpture', first published in Florence in 1568 , he gives several references to the various modifications of the lost wax process. In Chapter XXII, 'How to Fashion Vessels of Gold and Silver, Likewise Figurines and Vases', for instance, he writes:

'You may proceed to fashion in wax whatever graces may have place at lip or handle, improving on the model or design with which you started. These finished you can make them in all sorts of different ways, so many that they were wearisome to recount.'

He also mentions the 'lost lead' variant of the process in Chapter XXIV:

'When the moulds are made, with due observance to the undercutting (I say this advisedly), lead castings are made from them, and these as well cleaned and worked up as the master may be minded; then they are cast in silver as I told you before. This is a particularly good way, because when the master has his lead model and has finished it up to suit his purpose, it can serve ever so many more times than a single casting.'

Cellini also employed the lost wax process in making his life size masterpieces and gave a detailed and dramatic account in his autobiography of the casting of his famous statue of Perseus - holding the head of Medusa high in his outstretched left arm - when the workshop caught fire.

Another concept born during the Italian Renaissance was the large portrait medal in gold, silver or bronze depicting the head or bust of princes or ecclesiastical dignitaries. Inspired by antique coins, but developed as commemorative pieces of personal jewellery in the earlier years before the method of striking from dies had been adopted, these were made by casting from a wax model (46). The earliest known medal from this period is that depicting the Byzantine Emperor John VIII who had attended a papal council in Florence in 1439 , in a last minute effort to reestablish the union of the Greek and Roman churches when his empire was threatened by the Turks. This was cast in the same year by the greatest expert in this field, Antonio Pisanello (47).

The Italian Renaissance culture spread eventually to the other countries of Europe during the sixteenth century, first of all to Germany. Here the goldsmiths of Augsburg, Nürnberg and elsewhere did not 
necessarily make their own wax models, these sometimes being produced by specialist pattern carvers or Formschneider, and the possession of a good collection of such models was an essential part of a goldsmith's equipment. Alternatively, the original model might be carved in wood for use in the indirect process of casting. One of the leading goldsmiths in the late sixteenth century was Wenzel Jamnitzer of Nürnberg, who was followed by his grandson Christoph. An interesting painting by Lorenz Strauch, dated 1597 , shows Christoph holding a modelling tool in his right hand and a wax model in his left, indicating his wish to emphasise that he could produce his own models (48).

\section{The New World}

The creative energy characteristic of the Italian Renaissance took a rather different direction in Spain. Only a decade after the first voyage to the Americas made by Christopher Columbus, the Spanish monarchs Ferdinand and Isabella were preparing to establish settlements along the coast of the mainland with the object of searching for gold. By 1 534, a successful expedition had reached the Sinú region in north western Colombia and other exploratory bands were to follow. Here the Spaniards were astonished to find not only great quantities of gold worn as personal ornaments or in the form of votive figures, just as in the Near East many centuries earlier, for intercession with the gods, but a highly developed technique of lost wax casting. These objects were traded over long distances, some communities supporting full time metal workers, but others relying upon itinerant smiths, and many of the spectacular products were customarily buried with the dead.

Robbing of the burial mounds immediately became a major occupation with the Spaniards, and as is well known vast quantities of beautiful gold objects were melted down and the bullion sent home to Spain. Fortunately, many more have been unearthed in more recent years to disclose the extraordinarily skills of the natives and the whole subject has been well reviewed by Warwick Bray in 1 971, and later in this journal (49). An enormous collection has been assembled in the Museo del Oro in Bogota, and a selection from this has recently been exhibited in London and Hanover, as well as in Australia, giving many opportunities to appreciate the technical abilities of their makers, while the catalogues of these exhibitions provide invaluable sources of information on these superb castings and their methods of production (50). There is a slight possibility that the concept of lost wax casting reached the South American continent by sea from the Far East, but it seems more likely that it was a matter of independent invention, complicated though it is. In any case the process seems to

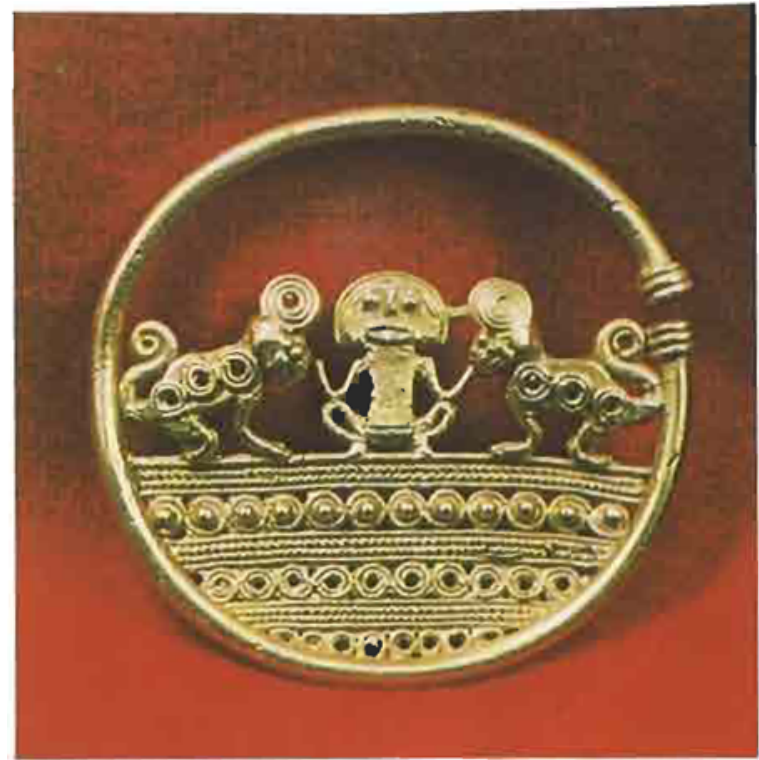

One of a pair of ear ornaments from the Sinu area of Colombia made by the lost wax process in the goldcopper alloy tumbaga. The delicate modelling of the wax original is only one example of the highly skilled technique developed by the Indians of South Anerica many years prior to the Spanish conques!

Photograph by courtesy of the Museo del Oro, Bogota

This unsuccessful casting of a similar omament, also nade in tumbaga in the Sinú region, slill has its sprne in position and clearly shows the method of casting. In preparing the mould the pre-Columbian Indians nixed clay witlı coarsely ground charcoal, giving a porosity for the escape of air and gases so that there was no need for risers Photograph by courtesy of the Musco del Oro, Bogota

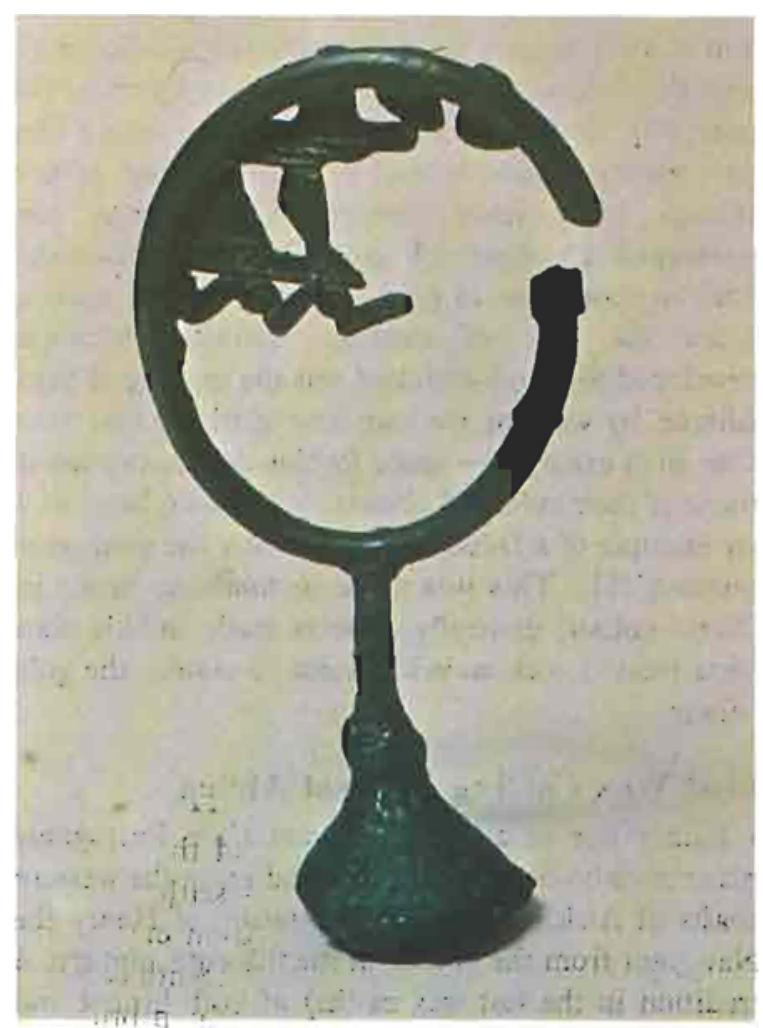




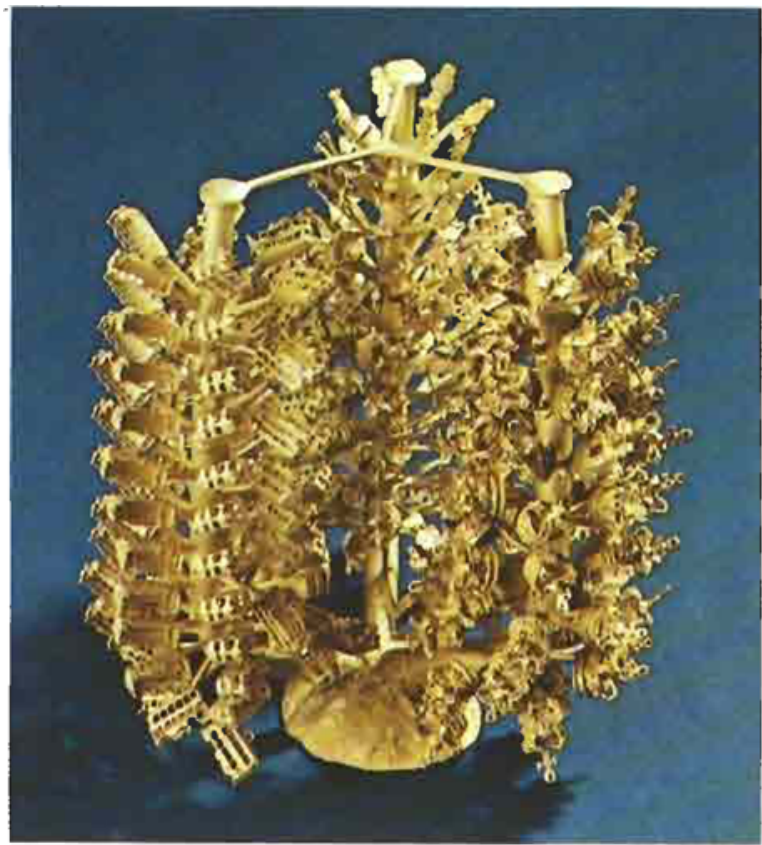

The modern technique of investment casting with improved waxes, mould materials and machines, makes it possible to produce numerons small castings in one operation. This 'tree', some 20 centimetres in height, first built np in the wax by attaching individnally produced models to the three central runners, yields over three hundred castings in carat gold

Pholograph by courtesy of Johnson Matthey Metals Limited

have become fully developed in its sundry variations many centuries before the Spanish conquest.

The method appears to have been adopted further south in Peru in the seventh or eighth centuries A.D. and to have spread slowly northwards via Colombia into the Panama area, reaching Mexico by about the year 900 . Both solid and hollow casting over a clay core were practised as well as the production of wax models from stone moulds. The Indians also developed a copper-rich gold alloy called tumbaga both to economise in gold and to lower the melting point for ease of casting. Another technique developed to a high standard was the making of 'false filigree' by working the wax into relatively fine wire. One such example - space forbids the illustration of more of their splendid objects - is shown here, as is an example of a failed casting to show the method of pouring (51). This was made in tumbaga, hence its darker colour; generally, objects made in this alloy were treated with an acidic juice to restore the gold colour.

\section{Lost Wax Casting in West Africa}

Rather less of a surprise awaited the Portuguese mariners who began to explore and settle the western coasts of Africa under the inspiration of Henry the Navigator from the middle of the fifteenth century. A tradition in the lost wax casting of both bronze and gold was found among the natives there but, unlike the situation in South America, it seems clear that European craftsmen later helped to introduce technical improvements. How the concept of lost wax casting reached this part of the African continent is most difficult to envisage. It is possible that the Carthaginians who voyaged in these waters searching for gold may have introduced the idea, or that Arabs from North Africa, also seeking gold in present day Ghana and Nigeria from the eighth century onwards, prompted the technique, but it is more likely that it was not in use until the thirteenth century. Gold figurines from these areas travelled widely and have been found as far north as Tripoli (52). The traditional craft remains alive to this day, represented by the well known bronzes from Benin and Ifé, while among the Tuareg and Inadan remote tribesmen of the Sahara the technique is still practised.

\section{The Later Centuries in Europe}

Throughout the seventeenth and eighteenth centuries, lost wax casting was used mainly for small bronzes and their reproduction, particularly in France, although of course its employment for individual pieces of gold jewellery continued. In England, the great Matthew Boulton was responsible for a large output of ormolu decorative mounts and fittings produced in this way at his Soho works in Birmingham between the years 1768 and 1782 .

The demand for small sculpture had grown considerably by the early nineteenth century and to meet this, some degree of mechanisation began to be adopted. One of the leading exponents was Antoine Louis Barye, the son of a Paris goldsmith, who produced his own wax models and who later acquired a reducing machine by means of which he could rapidly make miniatures of life size statues. This activity was severely curtailed however, when by 1850 the electroforming process was introduced by the Elkingtons, a method that could yield statuettes quickly and cheaply.

Individual artists still employed the lost wax process none the less and such disparate masters as Degas in France and Fabergé in Russia made use of the method.

\section{Modern Mechanisation of the Process}

The real transformation from a one-off hand operated process to a mechanised system did not begin, however, until early in the present century, and then it was not in the goldsmithing or jewellery manufacturing industry but in dentistry. In 1907 , a Chicago dentist named W. H. Taggart succeeded in introducing a casting method for gold inlays together with a compressed gas device for forcing the molten gold into the cavity left by the melted-out wax (53). 
The major development in the gold industry began to take effect only in 1936 when a Danish engineer, Thoger Gronborg Jungersen, employed by a firm of jewellery manufacturers in Toronto, filed a patent for

'methods of casting metal to enable the production by moulding in a commercially economical manner of rings and other articles of jewellery having intricate patterns or designs which have hitherto been cut or shaped by hand.' (54)

The great advance introduced by Jungersen was the flexible rubber mould from which any required number of wax models could be produced, and this innovation was adopted throughout the industry. In more recent years, highly ingenious casting machines have been developed to facilitate the rapid production in quantity of small gold castings. These were described in detail by Gainsbury in a recent issue of this journal (55). As well as improved machines, new types of both waxes and investment materials have been introduced to improve still further the efficiency of the process and the quality of the products.

\section{Acknowledgements}

In the preparation of this necessarily brief review of an immense subject extending over more than five thousand years and four conlinents - the examples and illustrations could have been multiplied many times - the writer has benefitted greatly from discussions with a number of archaeologists who have all been most generous with their time and considered opinions. They include $M r$. T. C. Mitchell, Mr. T. G. H. James, Dr. Ian Stead, Mrs. Leslie Webster, Mrs. Jessica Rawson, Miss Judith Swaddling, Mr. W. A. Oddy and Dr. Paul Craddock, all of the British Museum; Professor Stuart Piggott, Professor Colin Renfrew, Dr. P. R. S. Moorey, Dr. Warwick Bray, and Dr. Lloyd Laing. His thanks also go to Professor Boris Piatrovsky, Dr. Pessah Bar-Adon and Mr. Raghnall O'Floinn for the provision of photographs.

\section{References}

1 P. Amiet, 'Elam', Auvers-sur-Oise, 1966, pp. 88-89

2 I. Bernabo-Brea, 'Poliochni, Citta Prehistorica Nell 'Isola di Lemnos', Rome, 1964, p. 67 and p. 591 ; K. Branigan, 'Aegean Metalwork of the Early and Middle Bronze Age', Oxford, 1974, pp. 77-83

3 P. Bar-Adon, Isr. Explor f., 1962, 12, 215; Archaeology, 1963, 16, 251

4 Sir Leonard Woolley, 'Ur Excavations', Vol. II, London, 1934, p. 78

5 S. Lloyd, 'The Archaeology of Mesopotamia', London, 1978, p. 128

6 H. Frankfort, Oriental Inst. Pub. 44, Chicago, pp. 39-42

7 H. Z. Kosay, 'Alacahüyuk', Ankara, 1957; E. Akurgal and M. Hirmer, 'The Art of the Hittites', London, 1962

8 T. Özgüc and T. Akok, 'Horoztepe; An Early Bronze Age Settlement and Cemetery', Ankara, 1958, p. 47

9 'The Dawn of Art', edited by $M$. Artamonov, Leningrad, 1974, p. 156

10 Sir Mortimer Wheeler, 'The Indus Civilisation', London, 1968, pp. 90-92; M. S. Vats, 'Excavations at Harappa', Vol. I, Delhi, 1940, p. 99; E. J. H. Mackay, 'Chanhu-daro Excavations', New Haven, CT., 1943, p. 164

11 R. A. Higgins, 'Greek and Roman Jewellery', London, 1961, pp. $52-53$

12 H. G. Buchholz and V. Karageorghis, 'Prehistoric Greece and Cyprus', London, 1973, pp. 101-102

13 'Cyprus B.C.', British Museum, London, 1979, p. 42

$14 \mathrm{H}$. Limet, 'Le Travail du Metal au Pays de Sumer au Temps de la III Dynastie d'Ur', Paris, 1960

15 M. T. Larsen, 'The Old Assyrian City-State and its Colonies', Copenhagen, 1976

$16 \mathrm{M}$. Schorr, 'Urkunden des altbabylonischen Zivil und Prozessrechts', Leipzig, 1913, p. 221; A. Ungnad, 'Altbabylonische Urkunden', Leipzig, 1909, p. 103

The writer is indebted to $\mathrm{Mr}$. T. C. Mitchell of the British Museum and to Mr. P. S. Salinger of the School of Oriental and African Studies for these references

17 Sir Leonard Woolley, 'Alalakh (Tell Atchana)', London, 1955

18 C. C. Mattusch, Hesperia, 1977, 46, 380-389

19 S. I. Rudenko, 'Frozen Tombs of Siberia', London, 1970

20 W. Watson, 'Cultural Frontiers in Ancient East Asia', Edin burgh, 1971, pp. 76-77; 'Arts of the Eurasian Stcppelands', edited by P. Denwood, Percival David Foundation of Chinese Art, London, 1977

21 P. R. S. Moorey, 'Catalogue of Ancient Persian Bronzes in the Ashmolean Museum', Oxford, 1971, pp. 292-295

22 S. Haynes, 'Etruscan Sculpture', 'Etruscan Bronze Utensils', British Museum, London, 1971 and 1974

23 W. Schurmeyer, Dtsch. Goldschmiede Z., [931, 13, 128-132

24 Professor S. Piggott, private communication

25 J. M. de Navarro, Antiquity, 1928, 2, 423

26 J. Brailsford and J. E. Stapley, Proc. Prehist. Soc., 1972, 38, 219-234

27 H. Schliemann, 'Troy and its Renuains', New York, 1875, p. 173
$28 \mathrm{Sir}$ Leonard Woolley, op, cit, ref. 17, p. 273

29 J. V. Canby, Iraq, 1965, 27,

30 R. F. Tylecote, 'Metallurgy in Archaeology', London, 1962, pp. $125-128$

31 Professor S. Piggott, private communication

32 K. R. Maxwell-Hyslop and W. H. M. Hodges, Iraq, 1964, 26, 50-53

33 J. Ternbach, Expedition, 1970, 12, (3), $41-42$

34 A. Oldeberg, 'Metallteknik under Vikingatio och Medelted', Stockholm, 1966, pp. 256-260

35 G. Wainwright and M. Spratling, Antiquity, 1973, 47, 109.130

36 J. Foster, British Museum Occasional Papers No. 12, London, 1980

I am grateful to Miss Foster for allowing me access to this paper before its publication.

37 Sir John Marshall, 'Taxilia', Vol. II, Cambridge, 1951, pp. 616-62

38 M. V. Krishnan, 'Cire Perdue Casting in India', New Delhi, 1976; S. K. Saraswati, F. Indian Soc. Orient. Art, 1936, IV, (2), 139

39 J. Rafters, 'Prehistoric Ireland', London, 1951; F. Henry, 'Irish Art in the Early Christian Period', London, 1947; A Mahr, 'Christian Art in Ancient Ireland', Vol. II, Dublin, 1941, p. 41

$40 \mathrm{~L}$. Laing, 'The Archaeology of Late Celtic Britain and Ireland', London, 1975, p. 253

41 B. Arrhenius, in 'Gold Age and Viking Art in Sweden', Stockholm, 1965

42 J. G. Hawthorne and C. S. Smith, 'On Divers Arts, The Treatise of Theophilus', Chicago, 1963; C. R. Dodwell, Gold Bull., 1971, 4, (3), 51-55

43 C. Oman, 'The Gloucester Candlestick', Victoria and Albert Museum, London, 1958

44 A. Ratcliffe, 'European Bronze Statuettes', London, 1966

45 C. R. Ashbee (transl.), "The Treatises of Benvenuto Cellini on Goldsmithing and Sculpture', London, 1888

46 G. F. Hill, 'Medals of the Renaissance', Oxford, 1920, pp. 19-30

47 R. Weiss, 'Pisanello's Medallion of the Emperor John VIII Palacologus', British Museum, London, 1966

$48 \mathrm{~J}$. F. Hayward, "Virtuoso Goldsmiths and the Triumph of Mannerism', London, 1976

49 W. Bray, Proc. R. Anthropol. Inst. 197I, 1972, 25-43; Gold Bull., 1978, 11, (4), 136-143

50 'The Gold of El Dorado', Royal Academy of Arts, London, 1978; 'El Dorado Colombian Gold', Australian Art Exhibitions Corp., Sydney, 1978; 'El Dorado - Der Traum vom Gold', Hanover, 1979

51 A. $-M$. Falchetti, 'The Goldwork of the Sinu Region, Northern Colombia', M. Phil. Dissertation, University of London Institute of Archaeology, 1976

52 D. Williams, 'Icon and Image', London, 1974

53 W. H. Taggart, Dent. Cosmos, 1907, 49, 1117-1121

54 T. G. Jungersen, British Patent 449062 (1936)

55 P. E. Gainsbury, Gold Bull., 1979, 12, (1), 2-8 